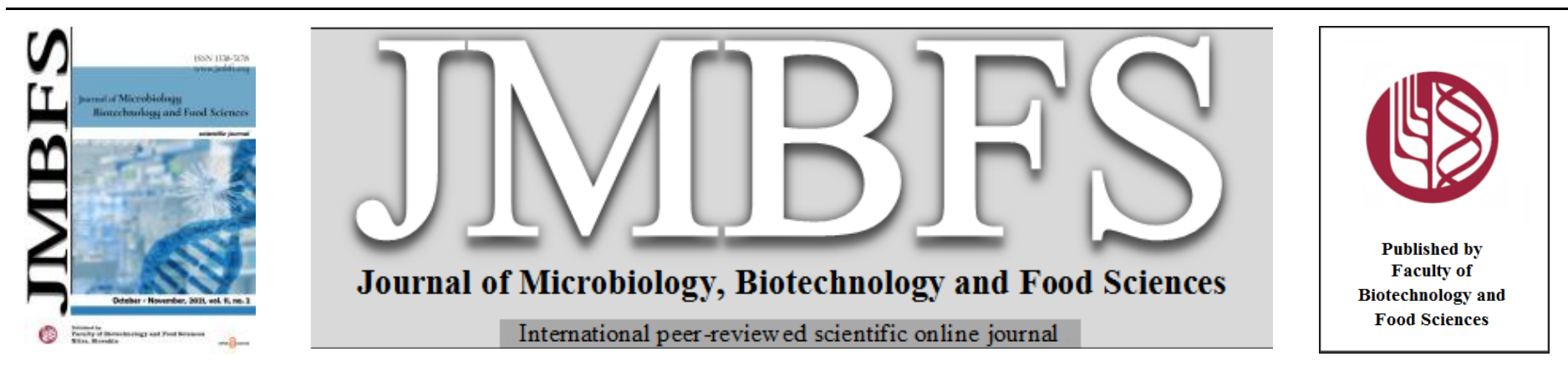

\title{
DESIGN AND SYNTHESIS OF NOVEL PYRIMIDINE ANALOGS AS ANTI-TUBERCULAR AGENTS TARGETING THYMIDINE KINASE DOMAIN
}

\author{
Jainey P. James ${ }^{l}$, Jane B. Mathew ${ }^{1}$, Ishwar Bhat K. ${ }^{1}$, Pankaj Kumar ${ }^{1}$, Aiswarya T.C ${ }^{1}$
}

Address(es):

${ }^{1}$ Department of Pharmaceutical Chemistry, Nitte (Deemed to be University), NGSM Institute of Pharmaceutical Sciences (NGSMIPS), Deralakatte, Mangaluru575018, Karnataka, India.

*Corresponding author: janej@nitte.edu.in

https://doi.org/10.15414/jmbfs.1744

\section{ARTICLE INFO}

Received 30. 5. 2019

Revised 23. 4. 2021

Accepted 23. 4. 2021

Published 1. 10. 2021

Regular article

open $\partial_{\text {ACCESS }}$

\begin{abstract}
The inhibition of the enzyme TMP kinase (TMPKmt), is hypothesized as a significant therapy for tuberculosis. A series of designed pyrimidines were synthesized to inhibit the enzyme TMPKmt and evaluated for their enzyme-ligand interactions, antitubercular, physiochemical and ADMET properties. The pyrimidines were synthesized from chalcones and guanidine as the cyclizing agent. The molecular interactions were studied by Autodock 4.0 and physicochemical, druglikeness and ADMET properties were analysed by Molinspiration, Chemsketch program and admetSAR prediction tools. The confirmation of the synthesized titled compound's structures was by spectral analysis. Also, they were screened for their antitubercular activity. In silico studies reports that their physicochemical, ADMET and druglikeness properties were found to be in standard limit, which infers that, these compounds may not have problems with oral bioavailability. Molecular docking studies showed that the pyrimidines have better enzyme inhibitory activity onTMPKmt.
\end{abstract}

Keywords: Pyrimidines, Molecular docking, Thymidine kinase, Antitubercular activity

\section{INTRODUCTION}

Tuberculosis is one of the deadliest diseases, which are caused by the bacteria, Mycobacterium tuberculosis (Dye et al., 1998; Dye et al., 2002). Globally, there were 9.2 million new cases and 1.7 million TB deaths in 2006, 0.7 million of which were in HIV-positive people and 0.2 million deaths (B. Greenwood et al., 2008). There are several flaws in existing drugs, the most prominent of which is the rise of drug resistance. For more than 20 years, no new medicines for tuberculosis have been discovered. Owing to the growing resistance to today's leading anti

tubercular drugs, new therapies are urgently needed, which stimulated the pursuit of novel targets for the disease tuberculosis. The application of computational tools in the identification of drug targets, especially for Mtb, can very quickly produce a list of reliable targets. The inactivation of suitable novel targets, which are responsible for bacterial metabolism, growth and viability, would lead to bacterial death, thus eliminating the drug-resistant strains and shortening the duration of the therapy (Zhang 2005; Mdluli et al., 2006).

In the development of antitubercular drugs, thymidine monophosphate kinase of Mycobacterium tuberculosis (TMPKmt) (Gasse et al., 2008) is an obvious target. TMPK is a vital enzyme in the metabolism of Mycobacterium tuberculosis, and also, it is the precise enzyme in dTTP synthesis. It is unlike human enzyme analogues (22\% homology). It catalyses the conversion of deoxythymidine monophosphate (dTMP) to deoxythymidine diphosphate (dTDP) using ATP as a phosphoryl donor (Lavie $\boldsymbol{e t}$ al., 1998; Ostermann $\boldsymbol{e} \boldsymbol{t}$ al., 2001). Due to its prospects as antimetabolites, TMPK inhibitors have gained considerable interest. Even, by inhibiting DNA synthesis in M. tuberculosis, these molecules can be promising leads in treating tuberculosis. Very few studies of lead generation and optimisation have been explored for TMPKmt inhibitors (Pochet et al., 2003; Pochet et al., 2010).

Pyrimidines have been investigated extensively among the plethora of nitrogencontaining heterocycles. This chemical moiety is of paramount importance due to its activities such as antitubercular (Breda et al., 2012), anticancer (El-Deeb et al., 2010), (Tan et al., 2014), antimalarial (Singh et al., 2013), antitumor (ElNassan et al., 2011), analgesic, anti-convulsant (Deng et al.,2011) etc. Since only limited reports are available about pyrimidines as anti-tubercular agents, hence, the design of novel pyrimidines with its target is a feasible choice (Singh et al., 2011).

With this data, a study has been focused on screening some compounds containing pyrimidine moiety by using computational tools. And the compounds with good binding energy will be synthesized, and further will proceed for their antitubercular activity screening.

\section{METHODOLOGY}

\section{Materials and methods used}

All the reagents were commercially obtained from Sigma Aldrich and utilized without further purification. Melting points were determined by capillary method and uncorrected. Shimadzu Perkin Ekmer 8201 Pc IR spectrometer (KBr Pellets), Bruker Avance II 400 NMR, JEOL SX- 102/DA-6000 FAB Mass spectrometer were used for recording IR, NMR and Mass spectra.

\section{Synthetic Methods}

Synthesis of 6-(pyridin-2-yl)-4-(aryl substituted) pyrimidin-2-amine (PM1PM10):

0.1 mole of chalcones, 0.01 mole of guanidine, and $20 \mathrm{ml}$ of potassium carbonate as catalyst were taken and were refluxed for $12 \mathrm{hrs}$. Then, it was cooled, poured to ice and dilute acetic acid was added for acidification. Ethanol was used for recrystallisation (Singh $\boldsymbol{e t}$ al., 2011). TLC medium was Ethylacetate:Chloroform(8:2), which was used for analysing purity periodically (Scheme1). 
Scheme-1 Synthesis of Pyrimidines<smiles>[R]c1ccc(C(C)=O)cc1</smiles>

$\mathrm{R}=\mathrm{Br}, \mathrm{Cl}, \mathrm{F}, \mathrm{NO}_{2}, \mathrm{NH}_{2}, \mathrm{OH}, \mathrm{CH}_{3}, \mathrm{OCH}_{3}$

Spectral data:

PM1: 6-(pyridin-2-yl)-4-(4-bromophenyl) pyrimidin-2-amine

IR (cm-1): 3415.8, 3347.7 (aromatic NH2 str), 3096 (aromatic CH str), 1626 $(\mathrm{C}=\mathrm{C}$ str $), 1652(\mathrm{C}=\mathrm{N}$ str $), 683(\mathrm{C}-\mathrm{Br})$.

${ }^{1}$ H NMR $(\delta$ ppm): 6.98 (s, 2H, NH2), 7.30-8.15 (m, 9H, Ar- H).

Mass $(\mathrm{m} / \mathrm{z}):\left(\mathrm{M}^{+}\right) 327$

PM2: 6-(pyridin-2-yl)-4-(4-chlorophenyl) pyrimidin-2-amine

IR (cm-1): $3421.5,3343.9$ (aromatic NH2 str), 3084 (aromatic CH str), 1680 $(\mathrm{C}=\mathrm{C}$ str $), 1671(\mathrm{C}=\mathrm{N}$ str $), 857(\mathrm{C}-\mathrm{Cl})$.

${ }^{1} \mathrm{H}$ NMR $(\delta \mathrm{ppm}): 6.81(\mathrm{~s}, 2 \mathrm{H}, \mathrm{NH} 2), 7.39-8.71(\mathrm{~m}, 9 \mathrm{H}, \mathrm{Ar}-\mathrm{H})$. Mass $(\mathrm{m} / \mathrm{z}):\left(\mathrm{M}^{+}\right) 282$

PM3: 6-(pyridin-2-yl)- 4-(4-fluorophenyl) pyrimidin-2-amine

IR (cm-1): 3402.1, 3392.9 (aromatic NH2 str), 3121.4 (aromatic $\mathrm{CH}$ str), 1671.7

$(\mathrm{C}=\mathrm{C}$ str) $1664.3(\mathrm{C}=\mathrm{N}$ str $), 1401.3(\mathrm{C}-\mathrm{F})$

${ }^{1} \mathrm{H}$ NMR $(\delta \mathrm{ppm}): 6.46(\mathrm{~s}, 2 \mathrm{H}, \mathrm{NH} 2), 7.12-8.91(\mathrm{~m}, 9 \mathrm{H}, \mathrm{Ar}-\mathrm{H})$.

Mass $(\mathrm{m} / \mathrm{z}):\left(\mathrm{M}^{+}\right) 266$

PM4: 6-(pyridin-2-yl) -4-(4-nitrophenyl) pyrimidin-2-amine

IR (cm-1): 3393.2, 3376.9 (aromatic NH2 str), 3222.8 (aromatic CH str), 1689.2 $(\mathrm{C}=\mathrm{C}$ str), 1634.6 (C=N str), $1543.3(\mathrm{C}-\mathrm{NO} 2)$.

${ }^{1} \mathrm{H} \mathrm{NMR}(\delta \mathrm{ppm}): 6.55$ (s, 2H, NH2), 8.01-8.99 (m, 9H, Ar- H).

Mass $(\mathrm{m} / \mathrm{z}):\left(\mathrm{M}^{+}\right) 293$.

PM5: 6-(pyridin-2-yl) -(4-hydroxyphenyl) pyrimidin-2-amine

IR (cm-1): 3433.9, 3391.3 (aromatic NH2 str), 3451.3 (aromatic CH str), 1672.8 $(\mathrm{C}=\mathrm{C}$ str $), 1672.7(\mathrm{C}=\mathrm{N}$ str $), 1423.7(\mathrm{C}-\mathrm{OH})$

${ }^{1} \mathrm{H}$ NMR $(\delta \mathrm{ppm}): 6.63(\mathrm{~s}, 2 \mathrm{H}, \mathrm{NH} 2), 7.09-8.87(\mathrm{~m}, 9 \mathrm{H}, \mathrm{Ar}-\mathrm{H}), 5.63(\mathrm{~s}, 1 \mathrm{H}$, $\mathrm{OH})$.

Mass (m/z): $\left(\mathrm{M}^{+}\right) 264$

\section{Antitubercular activity}

The method adopted for the antitubercular study was microplate Alamar blue assay (Collins et al.,1997) against M.tuberculosis. The diluted serial compounds $(0.2$ to $100.0 \mu \mathrm{M})$ and Middlebrook $7 \mathrm{H} 9$ broth $(100 \mu \mathrm{l})$ containing Mycobacterium tuberculosis was poured to 96 well plates. The standard used was Isoniazid. After the sealing off the plates, incubation was done for seven days at $37^{\circ} \mathrm{C}$. After, the addition of the dye, it was re-incubated for $24 \mathrm{~h}$. The changes in the colour were noted, which was interpreted for pink as the growth of bacteria and blue as vice versa.

\section{Software used}

The software used for molecular docking is Autodock 4.0 (Goodsell $\boldsymbol{e t}$ al., 1996) and the procedure followed for performing protein and ligand preparation is described elsewhere (Vanommeslaeghe et al., 2010; Morris et al., 1998; Chennu et al., 2015). Ligands were designed with the basic pharmacophore (pyridine) using pyrimidine as the primary nucleus with different cyclizing agents like guanidine and thiourea, substitutions like fluoro, chloro, bromo, nitro, methyl, methoxy, hydroxyl, and amino groups at 4 and 3 positions. About 12 compounds were designed for TMPKmt inhibition by incorporating these functional groups. Structure of the ligands was drawn using Chemsketch and SMILES notation was developed for the designed ligands. Molecular docking studies have carried out for compounds that have passed the ADMET (Feixiong et al., 2012) and Lipinski's rule of 5 (Lipinski, 2004).

\section{Docking studies}

\section{Target and Ligand Preparation}

TMPKmt crystal structure was downloaded from the Protein Data Bank with PDB ID as 4UNR (Naik et al. 2015). The repair commands module of AutoDock added the missing atoms. Before the docking process, the water molecules were removed, and $\mathrm{H}$-atoms were supplemented to the targets, to for tautomerism and ionise amino acids. The modified structure was then applied for semi-flexible dockings. The energy minimization was performed by Discovery Studio (Version 4.0, Accelrys Software Inc 2007, with the CHARMM force field (Vanommeslaeghe et al.,2010).

\section{Semi-flexible docking}

The energy scoring grid box was customized to 126,126 and $126 \AA$ (x, y, and $\mathrm{z}$ ) centered at $\mathrm{X}=0.041 ; \mathrm{Y}=-0.068$ and $\mathrm{Z}=0.128$ with 0.375 angstroms grid points spacing assigned with default atomic salvation parameters. Threedimensional grid boxes enclose the active site of the enzyme TMPKmt, which locates the ligand active binding site at the centre. Lamarckian Genetic Algorithm (LGA) (Morris et al., 1998) was the docking engine used in this study. After each LGA run, Autodock reports the best docking orientation, and the results were based on cluster analysis. The energy docking mode was found from a total of 10 docking modes. The lowest energy docking pose was chosen, from a total of 10 docking poses in each docking simulation.

\section{RESULTS AND DISCUSSION}

\section{Chemistry}

Chalcone and guanidine in equimolar quantities with anhydrous potassium carbonate as the catalyst resulted in pyrimidines in better yields (Table 1). The IR spectra of compound PM1 shows an aromatic peak at 3415.8 and $3347.7 \mathrm{~cm}$ ${ }^{1}$ which corresponds to the amino group and $\mathrm{C}=\mathrm{N}$ stretching at $1652 \mathrm{~cm}^{-1}$. In addition, the ${ }^{1} \mathrm{H}$ NMR spectra predicted the presence of two hydrogens at 6.98 $(\mathrm{s}, 2 \mathrm{H})$, which relates to aromatic $\mathrm{NH}_{2}$ group. Further, this compound got support from the mass spectrum, which depicted its molecular ion peak at 327 , which corresponds to its molecular weight.

Table 1 Physical data of synthesized pyrimidines

\begin{tabular}{lccccccc}
\hline Comp. Code: & $\mathbf{A r}$ & Molecular Formula & Physical State (crystals) & Mol. Wt & \% Yield & M.P $\left({ }^{\circ} \mathbf{C}\right)$ & R Value f \\
\hline PM1 & $4-\mathrm{Br}$ & $\mathrm{C} 15 \mathrm{H}_{11} \mathrm{BrN} 4$ & Brown & 327 & 68 & $196-198$ & 0.73 \\
\hline PM 2 & $4-\mathrm{Cl}$ & $\mathrm{C} 15 \mathrm{H}_{11} \mathrm{ClN} 4$ & Red & 282.73 & 67 & $182-184$ & 0.75 \\
\hline PM 3 & $4-\mathrm{F}$ & $\mathrm{C} 15 \mathrm{H}_{11} \mathrm{FN} 4$ & Red & 266.28 & 62 & $174-176$ & 0.75 \\
\hline PM 4 & $4-\mathrm{NO}_{2}$ & $\mathrm{C} 15 \mathrm{H}_{11} \mathrm{~N}_{5} \mathrm{O} 2$ & Red & 293.29 & 64 & $186-188$ & 0.67 \\
\hline PM 5 & $4-\mathrm{OH}$ & $\mathrm{C} 15 \mathrm{H}_{12 \mathrm{~N} 4 \mathrm{O}}$ & Brown & 264.29 & 50 & $174-176$ & 0.74 \\
\hline PM 6 & $4-\mathrm{NH}_{2}$ & $\mathrm{C} 15 \mathrm{H} 13 \mathrm{~N} 5$ & Brown & 263.3 & 48 & $184-186$ & 0.64 \\
\hline PM 7 & $4-\mathrm{CH}_{3}$ & $\mathrm{C} 16 \mathrm{H} 14 \mathrm{~N} 4$ & Brown & 262.32 & 39 & $176-179$ & 0.76 \\
\hline PM 8 & $4-\mathrm{OCH}_{3}$ & $\mathrm{C} 16 \mathrm{H} 14 \mathrm{~N} 4 \mathrm{O}$ & Red & 278.31 & 45 & $186-188$ & 0.79 \\
\hline PM9 & $3-\mathrm{Br}$ & $\mathrm{C} 15 \mathrm{H}_{11} \mathrm{BrN} 4$ & Red & 327 & 57 & $186-188$ & 0.73 \\
\hline PM10 & $3-\mathrm{Cl}$ & $\mathrm{C} 15 \mathrm{H}_{11} \mathrm{ClN} 4$ & Red & 282.73 & 56 & $172-174$ & 0.72 \\
\hline
\end{tabular}




\section{Antitubercular activity}

The titled compounds were screened for their antitubercular activity by in vitro methods. All the compounds were found to have good antitubercular activity, and results are tabulated in Table 2. Compounds PM2 and PM4 were found to be active as standard, and their activity is due to the substitution of chloro and nitro in the 4-position of benzyl group of PM2 and PM4 respectively and the presence of the core groups pyridine and pyrimidine must have also contributed equally, with MIC value of $0.2 \mu \mathrm{M}$. With various other changes, an extensive structureactivity relationship could be derived in the future.

Table 2 Antitubercular activity of synthesized pyrimidines

\begin{tabular}{lcc}
\hline Comp.Code & $\underline{\mathbf{A r}}$ & MIC in $\boldsymbol{\mu M}$ \\
PM1 & $4-\mathrm{Br}$ & 0.8 \\
PM2 & $4-\mathrm{Cl}$ & 0.2 \\
PM3 & $4-\mathrm{F}$ & 0.8 \\
PM4 & $4-\mathrm{NO} 2$ & 0.2 \\
PM5 & $4-\mathrm{OH}$ & 0.8 \\
PM6 & $4-\mathrm{NH} 2$ & 3.125 \\
PM7 & $4-\mathrm{CH} 3$ & 12.5 \\
PM8 & $4-\mathrm{OCH} 3$ & 12.5 \\
PM9 & $3-\mathrm{Br}$ & 3.125 \\
PM10 & $3-\mathrm{Cl}$ & 3.125 \\
Standard & Isoniazid & 0.2 \\
\hline
\end{tabular}

\section{In silico studies}

The predictions of drug-likeness and pharmacokinetic properties (ADMET) were performed by online tools molinspiration and admetSAR. The analogues owned desired physicochemical properties by satisfying all the Lipinski's RO5 properties with no violations from the standard limits (Table 3). The partition coefficient of all the compounds was found to be good values (1-3), which is essential for the absorption and distribution of drugs. ADMET properties were predicted, and it was found that all the parameters were within the acceptable range when compared with the standard (Table 4). Thus, all the hits were predicted with excellent physicochemical and druggable properties, rendering them good oral bioavailability.

Table 3 In silico physicochemical properties of synthesized pyrimidines

\begin{tabular}{lccccccc}
\hline $\begin{array}{l}\text { Comp. } \\
\text { Code: }\end{array}$ & Mol. Wt & \multicolumn{2}{c}{ Log P nNHAcc nHDon } & tPSA & nrobs & $\begin{array}{c}\text { Molar volume } \\
\mathbf{c m}^{\mathbf{3}}\end{array}$ \\
\hline PM1 & 327 & 3.04 & 4 & 2 & 64.7 & 2 & 243.57 \\
\hline PM 2 & 282.73 & 2.91 & 4 & 2 & 64.7 & 2 & 213.9 \\
\hline PM 3 & 266.28 & 2.4 & 4 & 2 & 64.7 & 2 & 206.1 \\
\hline PM 4 & 293.29 & 2.19 & 7 & 2 & 110.52 & 3 & 213.7 \\
\hline PM 5 & 264.29 & 1.75 & 5 & 3 & 84.93 & 2 & 200.3 \\
\hline PM 6 & 263.3 & 1.31 & 5 & 4 & 80.72 & 2 & 204.2 \\
\hline PM 7 & 262.32 & 2.68 & 4 & 2 & 64.70 & 2 & 218.2 \\
\hline PM 8 & 278.31 & 2.29 & 5 & 2 & 73.93 & 3 & 225.9 \\
\hline PM 9 & 280.36 & 2.22 & 4 & 2 & 64.70 & 2 & 243.34 \\
\hline PM 10 & 281.34 & 2.67 & 4 & 1 & 58.90 & 2 & 240.07 \\
\hline Isoniazid & 137.14 & -0.92 & 4 & 3 & 68.01 & 1 & 122.56 \\
\hline & & & & & & &
\end{tabular}

\section{Molecular docking}

The designed compounds were found to have excellent binding affinity to the enzyme. The ten compounds were docked with TMPKmt domain protein to calculate its binding energy and understand its molecular interactions, which is in charge of target inhibition. Table 5, depicts the docking score of the docked compounds with the enzyme TMPKmt, within the range of -8.4 to 9.3 Kcal/mol. Compounds PM3, PM7, PM8 obtained the best binding score ($9.3 \mathrm{Kcal} / \mathrm{mol}$ ). This may be due to the great involvement of van der Waals and pi-pi interactions with the amino acids of the target. Figure 1a, describes the TMPKmt domain inhibited complex formation with the compound PM3 of maximum binding energy $(-9.3 \mathrm{Kcal} / \mathrm{mol})$, by forming pi-pi interaction with the residue Y103. Also showed van der Waals interactions with the residues L52; F70; S104; S99; Y103; R107. Figure 1b explains the TMPKmt domain inhibited complex formation with the compound PM4 of binding energy (-9 $\mathrm{Kcal} / \mathrm{mol}$ ), by forming two pi-pi interaction with the residue Y103. The complex also displayed two hydrogen bond of distance of 2.046 and $2.134 \mathrm{~A}$ and van der Waals relations with the amino acid residues Y103; R74; R95; N100; F70; S104; Y103; R107. The obtained interactions were found to be similar for the other docked pyrimidines, with the active amino acid residues, such as, Y103; R74; R95; N100; F70; S104; Y103; R107 and further, showed pi-pi interactions with the residues $\mathrm{Y} 103$.
Table 4 In silico ADMET studies of pyrimidines

\begin{tabular}{lccccc}
\hline $\begin{array}{l}\text { Comp. } \\
\text { Code }\end{array}$ & BBB & HIA & $\begin{array}{c}\text { Caco-2 } \\
\text { permeability }\end{array}$ & $\begin{array}{c}\text { AMES } \\
\text { toxicity }\end{array}$ & Carcinogenicity \\
\hline PM1 & 0.9209 & 1 & 0.7407 & $\begin{array}{c}\text { Non-AMES } \\
\text { toxic }\end{array}$ & Non-carcinogens \\
\hline PM 2 & 0.9368 & 0.9965 & 0.7801 & $\begin{array}{c}\text { Non-AMES } \\
\text { toxic }\end{array}$ & Non-carcinogens \\
\hline PM 3 & 0.9401 & 0.9965 & 0.7375 & $\begin{array}{c}\text { Non-AMES } \\
\text { toxic }\end{array}$ & Non-carcinogens \\
\hline PM 4 & 0.9012 & 1.0000 & 0.6035 & AMES toxic & Non-carcinogens \\
\hline PM 5 & 0.84 & 0.9930 & 0.6 & AMES toxic & Non-carcinogens \\
\hline PM 6 & 0.8707 & 0.9933 & 0.7535 & $\begin{array}{c}\text { Non-AMES } \\
\text { toxic }\end{array}$ & Non-carcinogens \\
\hline PM 7 & 0.8993 & 1.0000 & 0.7718 & $\begin{array}{c}\text { Non-AMES } \\
\text { toxic }\end{array}$ & Non-carcinogens \\
\hline PM 8 & 0.93 & 1.0000 & 0.66 & AMES toxic & Non-carcinogens \\
\hline PM 9 & 0.8928 & 0.8997 & 0.6291 & $\begin{array}{c}\text { Non-AMES } \\
\text { toxic }\end{array}$ & Non-carcinogens \\
\hline PM 10 & 0.8480 & 0.9529 & 0.5000 & $\begin{array}{c}\text { Non-AMES } \\
\text { toxic }\end{array}$ & Non-carcinogens \\
\hline Isoniazid & 0.9832 & 0.9905 & 0.6274 & AMES toxic & Non-carcinogens \\
\hline
\end{tabular}

Table 5 Docking results of the pyrimidines with TMPKmt receptor domain

\begin{tabular}{|c|c|c|c|c|}
\hline $\begin{array}{l}\text { Comp. } \\
\text { Code: }\end{array}$ & $\begin{array}{l}\text { Docking } \\
\text { energy } \\
(\text { Kcal } / \mathrm{mol})\end{array}$ & $\begin{array}{l}\text { Hydrogen } \\
\text { bonds }\end{array}$ & $\begin{array}{c}\mathbf{P i}-\mathbf{P i} \\
\text { interactions }\end{array}$ & Van der waals interactions \\
\hline PM1 & -8.8 & $1(2.248)$ & Y103 & $\begin{array}{l}\text { R107,L171, } \\
\text { L62,N100, } \\
\text { Y103,S99, P37, S104, F70, } \\
\text { R74, } \\
\text { L52, R95, N100, R107 }\end{array}$ \\
\hline PM 2 & -9.2 & 0 & Y103 & $\begin{array}{c}\text { Y103, S99, P37, S104, F70, } \\
\text { R74 }\end{array}$ \\
\hline PM 3 & -9.3 & 0 & Y103 & $\begin{array}{l}\text { L52, Y103, } \\
\text { S99, N100, } \\
\quad \text { P37, S104, F70, R107 }\end{array}$ \\
\hline PM 4 & -9.0 & $\begin{array}{c}2(2.134, \\
2.046) \\
\text { R95:HH21 }\end{array}$ & Y103 & $\begin{array}{l}\text { R95, Y103, R107, N100, } \\
\text { S104, F70, R74 }\end{array}$ \\
\hline PM 5 & -9.0 & (2) & Y103 & $\begin{array}{l}\text { R107, N100, } \\
\text { L52,Y103, } \\
\text { S99, P37, S104, F70, R74 }\end{array}$ \\
\hline PM 6 & -8.8 & 0 & Y103 & $\begin{array}{l}\text { R107, L52, N100,Y103, } \\
\text { S99, P37, S104, F70, R74 } \\
\text { R107,R95 }\end{array}$ \\
\hline PM 7 & -9.3 & 0 & Y103 & $\begin{array}{l}\text { N100, Y103, } \\
\text { S99, P37, S104, F70, R74 } \\
\text { R95,L52, }\end{array}$ \\
\hline PM 8 & -9.3 & 1 & Y103 & $\begin{array}{l}\text { Y103,N100, } \\
\text { S99, P37, S104, F70, R74 }\end{array}$ \\
\hline PM 9 & -8.4 & 0 & $\begin{array}{l}\text { Y103, } \\
\text { F70 }\end{array}$ & $\begin{array}{l}\text { L171, R95, R107, Y103, } \\
\text { S99, P37, S104, F70, R74 }\end{array}$ \\
\hline PM 10 & -8.7 & $\begin{array}{c}1 \\
\text { R74:HH12 }\end{array}$ & $\begin{array}{l}\text { Y103, } \\
\text { F70 }\end{array}$ & Y103,S99, S104, F70, R74 \\
\hline
\end{tabular}

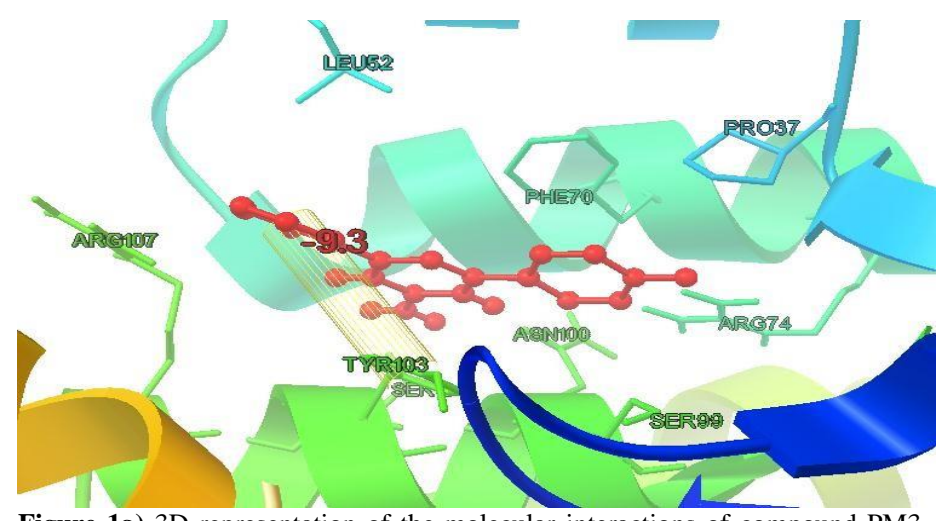

Figure 1a) 3D representation of the molecular interactions of compound PM3, within the binding pocket of protein and forming a pi-pi interactions with Y103 residue 


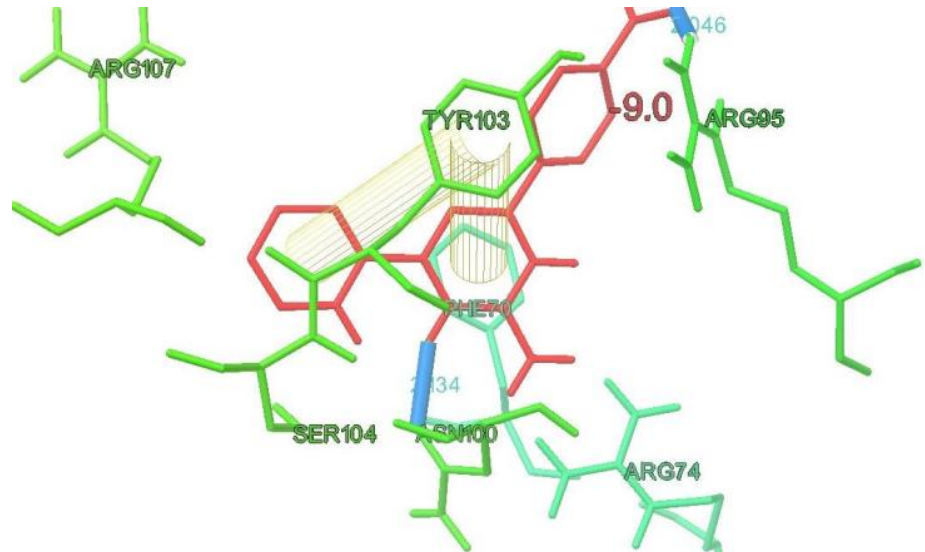

Figure 1b) 3D docking snapshot showing compound PM4 forming two hydrogen bonds shown in blue, two pi-pi interactions with Y103 residue

\section{CONCLUSION}

In the present investigation, different pyrimidine derivatives were designed, synthesized and screened for their in silico properties such as physicochemical, druglikeness, and ADMET and the toxic-less compounds were docked and aligned to the active pockets of the TMPKmt enzyme. The results thus obtained revealed that the amino pyrimidines may have a considerable impact on the enzyme inhibitory activity. From these computational data, the molecular interactions between the ligand pyrimidines and the enzyme TMPKmt have been obtained. Thus, docking studies have proved that these pyrimidine derivatives, as ligands have a strong affinity for the enzyme TMPKmt, which might be a reason for its antitubercular activity. In conclusion, the investigated pyrimidines are found to be suitable lead structures with better inhibitory action towards the target TMPKmt.

Acknowledgements: This study was funded by the Nitte University Research Grant (NURG/STF/01/7-2015). And the authors acknowledge NITTE (Deemed to be University), Mangaluru, for financial assistance, and NGSM Institute of Pharmaceutical Sciences, Mangaluru for providing the necessary facilities for the studies. Thanks also to Maratha Mandal Dental College, Belgaum for antitubercular tests, Director-SAIF, IISc, Bangaluru, and Director-CSRI, Lucknow, India for NMR and mass spectral analysis.

\section{REFERENCES}

Breda, A., Machado, P., Rosado, L. A., Souto, A. A., Santos, D. S., \& Basso, L. A. (2012). Pyrimidin-2(1H)-ones based inhibitors of Mycobacterium tuberculosis orotate phosphoribosyltransferase. European Journal of Medicinal Chemistry, 54, 113-122. https://doi:10.1016/j.ejmech.2012.04.031

Chennu, M.M.P.R., Abdul, R.S., Yejella, R.P. 2015. Molecular docking based screening of G6PS with 1,5 Benzothiazepine derivates for a potential inhibitor. Bioinformation, 11(12), 525-28. https://doi.org/10.6026/97320630011525

Collins, L.A., Franzblau, S.G. 1997. Microplate alamar blue assay versus bactec 460 system for high-throughput screening of compounds against Mycobacterium tuberculosis and Mycobacterium avium. Antimicrobial Agents and Chemotherapy, 41, 1004-9. https://doi.org/10.1128/aac.41.5.1004

Deng, X.-Q., Quan, L.-N., Song, M.-X., Wei, C.-X., \& Quan, Z.-S. (2011) Synthesis and anticonvulsant activity of 7-phenyl-6,7-dihydro-[1,2,4]triazolo[1,5a]pyrimidin-5(4H)-ones and their derivatives. European Journal of Medicinal Chemistry, 46(7), 2955-2963. https://doi:10.1016/j.ejmech.2011.04.020

Discovery Studio. Modeling Environment, Release x.x, San Diego: Accelrys Software Inc.,2007.

Dye,C.,Garnett,G.P.,Sleeman,K.,Williams,B.G.1998.Prospects for world wide tuberculosis control under the WHO DOTS strategy. Directly observed shortcourse therapy. Lancet, 352, 1886-91. https://doi.org/10.1016/S01406736(98)03199-7

Dye, C., Espinal, M. A., Watt, C. J., Mbiaga, C., \& Williams, B. G. 2002. Worldwide Incidence of Multidrug Resistant Tuberculosis. The Journal of Infectious Diseases, 185(8), 1197-1202. https://doi:10.1086/339818

Dye, C.,Williams, B. G., Espinal, M. A., Raviglione, M. C. 2002. Erasing the world's slow stain: Strategies to beat multidrug resistant tuberculosis. Science , 295, 2042-2046. https://doi.org/10.1126/science.1063814.

El-Deeb, I. M., \& Lee, S. H. (2010). Design and synthesis of new anticancer pyrimidines with multiple-kinase inhibitory effect. Bioorganic \& Medicinal Chemistry, 18(11), 3860-3874. https://doi:10.1016/j.bmc.2010.04.037

El-Nassan, H. B. (2011). Synthesis and antitumor activity of novel pyrido[2,3d] $[1,2,4]$ triazolo[4,3-a]pyrimidin-5-one derivatives. European Journal of $\begin{array}{lll}\text { Medicinal } & \text { Chemistry, 2031-2036. }\end{array}$ https://doi:10.1016/j.ejmech.2011.02.055
Gasse, C., Douguet, D., Huteau, V., Marchal, G., Munier-Lehmann, H., Pochet, S. 2008. Substituted benzyl-pyrimidines targeting thymidine monophosphate kinase of Mycobacterium tuberculosis: Synthesis and in vitro anti-mycobacteria activity. Bioorganic \& Medicinal Chemistry, 16, 6075-85 https://doi.org/10.1016/j.bmc.2008.04.045

Goodsell, D.S., Morris, G.M., Olson, A.J. 1996. Automated docking of flexible ligands: Applications of AutoDock. J Mol Recognit, 9, 1- 5 https://doi.org/10.1002/(SICI)1099-1352(199601)9:1\%3C1::AID-

JMR241\%3E3.0.CO;2-6

Greenwood, B. 2008. A global action plan for the prevention and control of pneumonia. Bulletin of the World Health Organization, 86(5), 322. https://doi: 10.2471/BLT.08.053348

Feixiong., Cheng., Weihua. L.I., Yadi, Zhou., JieShen., Zengrui, W.U., Guixia, Liu., Philip, W., Yun., Tang. 2012. admetSAR: a comprehensive source and free tool for evaluating chemical ADMET properties. J. Chem. Inf. Model, 52(11), 3099-105. https://doi.org/10.1021/ci300367a

Kadry, H. H. (2014). Synthesis, biological evaluation of certain pyrazolo[3,4d]pyrimidines as novel anti-inflammatory and analgesic agents. Medicinal Chemistry Research, 23(12), 5269-5281. https://doi:10.1007/s00044-014-1079-9 Lavie, A., Ostermann, N., Brundiers, R., Goody, R. S., Reinstein, J., Konrad, M., et al. 1998. Structural basis for efficient phosphorylation of 3-azidothymidine monophosphate by Escherichia coli thymidylate kinase. Proc. Natl. Acad. Sci. U.S.A, 95, 14045-50. https://doi.org/10.1073/pnas.95.24.14045

Lipinski, C.A. 2004. Drug Discov Today Technol, 4, 337 https://doi.org/10.1016/j.ddtec.2004.11.007

Morris, G.M, Goodsell, D.S., Halliday, R.S., Huey, R., Hart, W.E., Belew, R.K., et al. 1998. Automated docking using a lamarckian genetic algorithm and empirical binding free energy function. J Comput Chem, 19, 1639-62. https://doi.org/10.1002/(sici)1096jcc10\%3E3.0.co;2-b

Mdluli, K., Spigelman, M. 2006. Novel targets for tuberculosis drug discovery. $\begin{array}{llll}\text { Current Opinion } & \text { Pharmacology, 659-67. }\end{array}$ https://doi.org/10.1016/j.coph.2006.06.004

Naik, M., Raichurkar, A., Bandodkar, B.S., et.al. 2015. Structure guided lead generation for M. tuberculosis thymidylate kinase (Mtb TMK):discoveryof3cyanopyridoneand1,6-naphthyridin-2-oneaspotentinhibitors,58(2),753-66. https://doi.org/10.1021/jm5012947

Ostermann, N., Schlichting, I., Brundiers, R., Konrad, M., Reinstein, J., Veit, T., et al. (2001). Human thymidylate kinase complexed with TP5A and a magnesium-ion. https://doi:10.2210/pdb1e2q/pdb

Pochet, S., Dugue', L., Labesse, G., Delepierre, M., Munier-Lehmann, H. 2003. Comparative study of purine and pyrimidine nucleoside analogues acting on the thymidylate kinases of Mycobacterium tuberculosis and of humans. Chem Bio Chem, 4, 742. https://doi.org/10.1002/cbic.200300608

Pochet, S., Dugue, L., Douguet, D., Labesse, G., \& Munier-Lehmann, H. 2010. ChemInform Abstract: Nucleoside Analogues as Inhibitors of Thymidylate Kinases: Possible Therapeutic Applications. ChemInform, 33(16), no-no. https://doi:10.1002/chin.200216207

Singh, K., Wan, B., Franzblau, S., Chibale, K., Balzarini, J. 2011. Facile transformation of biginelli pyrimidin-2 $(1 \mathrm{H})$-ones to pyrimidines. In vitro evaluation as inhibitors of Mycobacterium tuberculosis and modulators of cytostatic activity. European Journal of Medicinal Chemistry, 46(6), 2290-4. https://doi.org/10.1016/j.ejmech.2011.03.010

Singh, K., Kaur, H., Chibale, K., \& Balzarini, J. 2013. Synthesis of 4aminoquinoline-pyrimidine hybrids as potent antimalarials and their mode of action studies. European Journal of Medicinal Chemistry, 66, 314-323. https://doi:10.1016/j.ejmech.2013.05.046

Tan, Q., Zhang, Z., Hui, J., Zhao, Y., \& Zhu, L. (2014). Synthesis and anticancer activities of thieno[3,2-d]pyrimidines as novel HDAC inhibitors. Bioorganic \& Medicinal Chemistry, 22(1), 358-365. https://doi:10.1016/j.bmc.2013.11.021

Vanommeslaeghe, K., Hatcher, E., Acharya, C., Kundu, S., Zhong, S., Shim, J., et al. 2010. CHARMM general force field: A force field for drug-like molecules compatible with the CHARMM all-atom additive biological force fields. J Comput Chem, 31, 671-90. https://doi.org/10.1002/jcc.21367

Zhang, Y. 2005. The magic bullets and tuberculosis drug targets. Annual Review $\begin{array}{llll}\text { Pharmacology and Toxicology, 529-64. } & \text { 45, }\end{array}$ https://doi.org/10.1146/annurev.pharmtox.45.120403.10012 